IMAGE

UNAVAILABLE

FOR COPYRIGHT

REASONS

Al-Quds University is on the Jerusalem side of the barrier that divides the city from the West Bank.

\title{
Palestinian unease sparks fresh calls for Israeli boycott
}

\section{Jim Giles}

For many who follow the Israeli-Palestinian conflict, Al-Quds University in Jerusalem is a beacon of hope. Of all the Palestinian universities, it is the only one that vigorously promotes interaction with Israeli institutions.

But dissent among its academics over such collaborations is becoming increasingly public. A survey of Al-Quds staff, released last month, suggests that most want to avoid joint projects while Israel continues to occupy the West Bank and Gaza.

Although the survey's methodology has come in for criticism, its findings are mirrored in recent Palestinian statements calling for a boycott of Israeli universities calls that look set to reignite the boycott debate elsewhere.

Al-Quds' policy owes much to its location in a suburb of Jerusalem, where travel to Israeli institutions is not hindered by the Israeli army checkpoints that dot the West Bank and Gaza. Senior staff have backed collaboration for more than a decade, bringing in millions of dollars of funding. At least 70 such projects are ongoing, says Hasan Dweik, the university's acting president.

But according to the recent survey, conducted by the university's employees' union, three-quarters of the university staff oppose collaborative projects. Al-Quds academics, who spoke to Nature on condition of anonymity, say they fear that by working with Israelis they are acquiescing to the occupation. "The projects are harmful because they give the impression that the best minds are working together and things are fine," says one faculty member.

Dweik is sympathetic to such fears, but argues that working with Israelis - who are better funded and often more experienced than their Palestinian colleagues - helps Al-Quds prepare for its role in a future Palestinian state. And, he says, it means that Israeli academics learn about Palestinian views. The survey results, he adds, are contradicted by researchers' actual behaviour: "More than 150 of our 300 academics are involved in joint projects, so how did the union get its result?"

Al-Quds staff who back the survey's findings acknowledged that the questions could have been more rigorously worded. But they point to public opposition among colleagues in the West Bank and Gaza as evidence that the result is representative.

Last July, for example, the Palestinian Campaign for the Academic and Cultural Boycott of Israel was launched. Spearheaded by Lisa Taraki, a sociologist at Birzeit University in the West Bank, the call has been backed by a coalition of academic trade unions from Palestinian universities.

This backing adds momentum to similar campaigns elsewhere, say British academics behind a proposal to boycott Israeli researchers. The UK campaign was launched in 2002 (see Nature 425, 444-449; 2003), and later this month Britain's Association of University Teachers will debate a motion to focus the boycott on specific universities, such as those linked with educational institutions in Israeli settlements in the Palestinian territories.

But despite moves from Palestinian academic organizations, those in favour of a boycott will struggle to win over other academics who have already opposed the idea, such as Michael Aizenman, a mathematical physicist at Princeton University in New Jersey. "As a tool for fostering progress in the Middle East, calls for intellectual boycott are highly counterproductive," he says.

\section{War of words deepens divide over biodefence funds}

Emma Marris, Washington

Relations between disgruntled microbiologists and their paymasters at the US National Institutes of Health (NIH) are degenerating in a very public way.

At issue: whether the influx of cash for studies on potential bioweapons is draining vital resources from basic research. This could leave the United States at far greater risk from natural disease outbreaks than it is ever likely to face from bioterrorism, the researchers fear.

More than $700 \mathrm{NIH}$-funded microbiologists signed a letter in the 4 March issue of Science (307, 1409-1410; 2005). In it they complained that since 2000 the number of grants for nonbiodefence-related studies had dropped by $41 \%$ for model microorganisms and by $27 \%$ for pathogenic microorganisms.

Anthony Fauci, director of the National Institute of Allergy and Infectious Diseases (NIAID), which handles much of the NIH's biodefence work, responded on 1 April with a letter, co-signed by NIH director Elias Zerhouni (Science 308, 49; 2005). He painted a rosier picture, saying "from 2000 to 2005, funding for NIAID nonbiodefense research increased by more than $50 \%$ ".

But this has simply inflamed the organizers of the original complaint. "Seven hundred and fifty people didn't sign this letter because they were confused and there is no issue," says Robert Landick, a bacteriologist at the University of Wisconsin in Madison. And Richard Ebright, a molecular biologist at Rutgers University in Piscataway, New Jersey, calls the reply "frankly dishonest".

So who is right? That depends on how you do the counting. Ebright focused on grants approved by four NIH review panels for work done at several different institutes. Fauci looked for basic microbiology grants across many more panels, including ones for epidemiology, behavioural research and even biodefence, but all within the NIAID.

"The applications are going other places and still getting funded," says John McGowan, the NIAID's director of extramural activities.

But researchers who work at the NIH are unhappy too. A group led by Michael Yarmolinsky of the National Cancer Institute has voiced similar complaints in a closed letter to institute bosses.

The relevant directors say that they will meet both groups to discuss the issue, probably in May. But overcoming the bitter divisions will not be easy. 